\title{
Geographical Patterns of Algal Communities Associated with Different Urban Lakes in China
}

\author{
Shengnan Chen ${ }^{1,2, *}$, Huiyan He ${ }^{1,2}$, Rongrong Zong ${ }^{1,2}$, Kaiwen Liu ${ }^{1,2}$, Yutian Miao ${ }^{1,2}$, \\ Miaomiao Yan ${ }^{1,2}$ and Lei $\mathrm{Xu}^{1,2}$ \\ 1 Shaanxi Key Laboratory of Environmental Engineering, Key Laboratory of Northwest Water Resource, \\ Environment and Ecology, MOE, School of Environmental and Municipal Engineering, Xi'an University of \\ Architecture and Technology, Xi'an 710055, China; JiandaHuiyanHe@163.com (H.H.); \\ 18792862643@163.com (R.Z.); kevin_wood1989@163.com (K.L.); miaoyutian728@163.com (Y.M.); \\ Ymmzsj@163.com (M.Y.); Leixugogogo@163.com (L.X.) \\ 2 Institute of Environmental Microbial Technology, Xi'an University of Architecture and Technology, \\ Xi'an 710055, China \\ * Correspondence: chenshengnan@xauat.edu.cn; Tel.: +86-29-8220-2854; Fax: +86-29-8220-2729
}

Received: 6 January 2020; Accepted: 4 February 2020; Published: 5 February 2020

\begin{abstract}
Urban lakes play an important role in drainage and water storage, regulating urban microclimate conditions, supplying groundwater, and meeting citizens' recreational needs. However, geographical patterns of algal communities associated with urban lakes from a large scale are still unclear. In the present work, the geographical variation of algal communities and water quality parameters in different urban lakes in China were determined. The water quality parameters were examined in the samples collected from north, central, south, and coastal economic zones in China. The results suggested that significant differences in water quality were observed among different geographical distribution of urban lakes. The highest total phosphorus $(\mathrm{TP})(0.21 \mathrm{mg} / \mathrm{L})$ and total nitrogen $(\mathrm{TN})(3.84 \mathrm{mg} / \mathrm{L})$ concentrations were found in XinHaiHu $(\mathrm{XHH})$ lake, it also showed highest the nitrate nitrogen $\left(\mathrm{NO}_{3}{ }^{-}-\mathrm{N}\right)(0.39 \mathrm{mg} / \mathrm{L})$, total organic carbon(TOC) $(9.77 \mathrm{mg} / \mathrm{L})$, and COD $\mathrm{Mn}(9.01 \mathrm{mg} / \mathrm{L})$ concentrations among all samples. Environmental and geographic factors also cause large differences in algal cell concentration in different urban lakes, which ranged from $4700 \times 10^{4}$ to $247,800 \times 10^{4} \mathrm{cell} / \mathrm{L}$. Through light microscopy, 6 phyla were identified, which includes Chlorophyta, Bacillariophyta, Cyanophyta, Dinophyta, Euglenophyta, and Cryptophyta. Meanwhile, the heat map with the total 63 algal community composition at the genus level profile different urban lakes community structures are clearly distinguishable. Further analyses showed that the dominant genera were Limnothrix sp., Synedra sp., Cyclotella sp., Nephrocytium sp., Melosira sp., and Scenedesmus sp. among all samples. The integrated network analysis indicated that the highly connected taxa (hub) were Fragilaria sp., Scenedesmus sp., and Stephanodiscus sp. The water quality parameters of $\mathrm{NO}_{3}{ }^{-}-\mathrm{N}$ and $\mathrm{NH}_{4}{ }^{+}-\mathrm{N}$ had significant impacts on the structural composition of the algal community. Additionally, RDA further revealed distinct algal communities in the different urban lakes, and were influenced by $\mathrm{NO}_{2}{ }^{-}-\mathrm{N}, \mathrm{Fe}$, and algal cell concentrations. In summary, these results demonstrate that the pattern of algal communities are highly correlated with geographic location and water quality on a large scale, and these results also give us further understanding of the complex algal communities and effectively managing eutrophication of urban lakes.
\end{abstract}

Keywords: urban lakes; algal bloom; algal community composition; geographical pattern

\section{Introduction}

With the rapid development of industrialization and the acceleration of urbanization, industrial water and drinking water have increased sharply [1]. Rivers and lakes in many cities have become long-term 
retention places for wastewater [2]. Urban lakes have the characteristics of drainage and water storage, regulating urban microclimate conditions, and meeting citizens' recreational needs [3-5]. Meanwhile, most of the urban landscape water bodies are static or semi-closed slow-flowing, which have the characteristics of small water environment capacity, relatively fragile ecosystem, and limited self-purification [6]. When the temperature is high, the water body rich in nitrogen and phosphorus nutrients is eutrophic, then algal blooms are formed. Abnormal reproduction of algae can cause odor and color problems, and destroy the ecological balance of water bodies [7]. In the past few decades, researchers have focused on the geographical distribution of microorganisms in oceans and temperate lakes, but relatively few studies have been done on urban lakes [8,9]. In recent years, the eutrophication of urban lakes, especially the outbreak of algae, is a potential huge hazard to people's lives due to its special geographical location and can seriously affect the development and utilization of water resources [10]. Thus, studies on the fundamental features of urban lake ecosystems are of great importance because they can provide a theoretical basis for our better recovery and management of urban lakes.

From the ecological point of view, changes in algal community diversity and composition are an important indicator for evaluating the water quality status and changing trend of rivers and lakes [11,12]. From an ecological point of view, the water environmental factors directly affect the population or community type of algal structural feature [13], on the other hand, the individual, population, or community of algae change can objectively reflect the changing discipline of water quality [14].Therefore, studying the relationship between algae and lake ecosystems is of great significance for the management and restoration of polluted water bodies. In recent years, efforts have been made to determine the algal community structures of seasonal and spatial variations [15]. However, few studies have addressed the characteristics of algal community structure in different urban lakes and the correlation of community structure with water quality in a large scale.

In freshwater ecosystems, parameters of urban polluted water such as $\mathrm{pH}$, total nitrogen, total phosphorus, and total organic carbon are important indicators for studying the relationship between geographical patterns of different cities and algal communities' structures [16-20]. Some researchers in the past have explored microbial community diversity in drinking water reservoirs [21], polluted rivers [22], and drinking water pipes [23]. In lake ecosystems, many reports have focused on revealing water temperature and nutrients and other important environmental factors affecting the growth of phytoplankton [24,25]. For instance, Habib et al. [26] studied the effects of seasonal changes and physical chemical factors on Locus Lomond and suggested that dissolved oxygen and nutrients were significantly related to the phytoplankton community distributions. However, few people probe the relationship between environmental factors and algal community in urban lakes under different spatial locations. In addition, only a limited number of studies have focused on interaction between algae under different spatial and environment condition, especially from a network perspective.

Recently, network has been widely used to explore the microbe co-occurrences and the environmental conditions that correlate with these eukaryotic plankton co-occurrence patterns [27-30]. Network analysis technology is a systematic analysis method for analyzing the intrinsic interaction between ecosystems by basic stochastic matrix theory. It is used to synthesize and characterize the molecular ecological network of microbial aggregation, providing a reliable method to understand of the potential interaction of complex microbial clusters [31]. In the network, each element (biological or genetic) can be described as a node, and the relationship between them can be described as a directed or undirected edge [32,33]. In our previous research, Zhang et al. [34] used co-occurrence network patterns to reveal different community interactions between aerobic/anoxic/aerobic and oxidation ditch systems in 18 geographically distributed wastewater treatment plants in nine provinces of China. Recently, Liu et al. [28] also used eukaryotic plankton co-occurrence networks and found that the cyanobacterial biomass cycle was remarkably linked to eukaryotes in two subtropical reservoirs over a 6-year period. Moreover, they further constructed four subnetworks based on distinct eukaryotic community succession periods and showed that the eukaryotic co-occurrence patterns were varied significantly correlating with cyanobacterial biomass. However, co-occurring networks 
associated with the algal coexistence at different levels of whole communities in different urban lakes have not been investigated.

To this end, the specific objectives of this work were to (1) determine the physiochemical parameters of urban lakes water quality, (2) investigate the algal cell morphology and community based on microscope, and (3) assess the relationship among water quality, algal concentration, and community structure, meanwhile, unveil algal community co-occurrence interactions in urban lakes distributed across a wide range of geographical locations. The results from this work will have certain reference significance for understanding the complex algal communities and effectively managing eutrophication of urban lakes.

\section{Materials and Methods}

\subsection{Site Description and Field Sampling}

To compare the algal community composition of urban lakes from various regions of China, sampling points were selected from different provinces located from the south to north $\left(25^{\circ} 04^{\prime} 10^{\prime \prime}\right.$

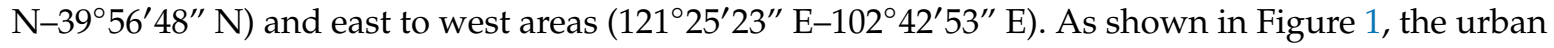
lakes were located in different geographic locations (Shaanxi, Sichuan, Henan, Jiangsu, Zhejiang, Jiangxi, Yunnan and Guangdong province, Inner Mongolia and Ningxia autonomous region, Shanghai and Beijing municipalities). The 16urban lakes are TieXi (TX), XinHaiHu (XHH), JinJi (JJ), ChangLe (CL), XiangShan (XS), AiXi (AX), HuiLongShan (HLS), GaoTie (GT), JinSha (JS), XiLiu (XL), ZiZhuYuan (ZZY), GuiLong (GL), ZhuZhai (ZZ), ZhongShan (ZS), West lake (WL), and YuNv (YN) (Table S1).

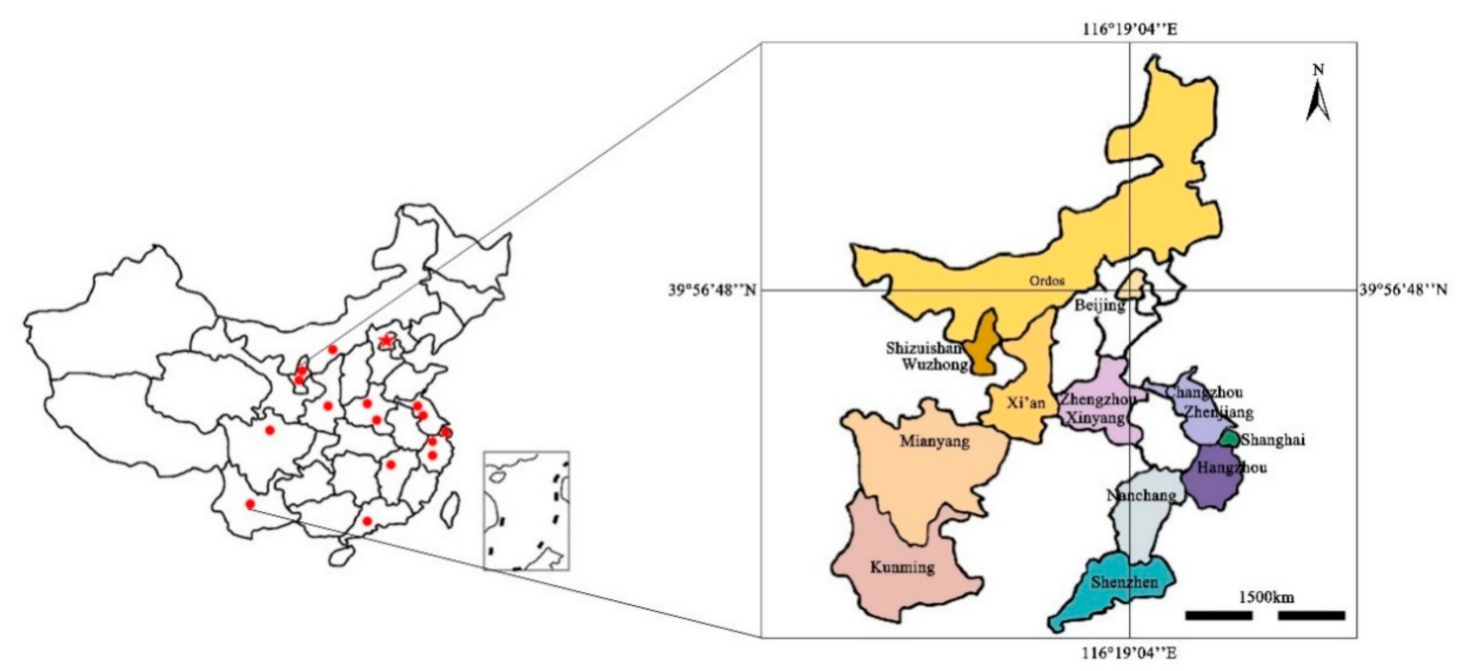

Figure 1. Geographical location of 16 urban lakes sampled in China.

The detailed information about urban lakes is listed in Table 1. The sampling process was undertaken in October 2018 and collected from the surface water of urban lakes. Water samples were collected at a depth of $0.5 \mathrm{~m}$ in each urban lake with sterilized polypropylene containers [35]. One part of the water sample was used to determine the water physicochemical characteristics and algal cell concentration. Another part of the water sample was used for algal morphology and community diversity examination. 
Table 1. The 16 urban lakes located in different areas of China.

\begin{tabular}{|c|c|c|c|c|c|c|c|c|}
\hline Urban Lakes & Provinces & Cities & Latitude & Longitude & Average Monthly Temperature $\left({ }^{\circ} \mathrm{C}\right)$ & Surface Area $\left(\mathrm{m}^{2}\right)$ & Urban Population & Built Year \\
\hline TieXi (TX) & Inner Mongolia & Ordos & $39^{\circ} 49^{\prime} 16^{\prime \prime} \mathrm{N}$ & $109^{\circ} 58^{\prime} 07^{\prime \prime} \mathrm{E}$ & 15.3 & $1.7 \times 10^{4}$ & $2.0 \times 10^{6}$ & 2005 \\
\hline XinHaiHu (XHH) & Ningxia & Shizuishan & $38^{\circ} 59^{\prime} 32^{\prime \prime} \mathrm{N}$ & $106^{\circ} 24^{\prime} 22^{\prime \prime} \mathrm{E}$ & 16.7 & $2.0 \times 10^{7}$ & $7.9 \times 10^{5}$ & 2004 \\
\hline Jinji (JJ) & Ningxia & Wuzhong & $37^{\circ} 56^{\prime} 10^{\prime \prime} \mathrm{N}$ & $106^{\circ} 08^{\prime} 36^{\prime \prime} \mathrm{E}$ & 17.3 & $2.0 \times 10^{8}$ & $1.3 \times 10^{6}$ & Qin and Han Dynasties \\
\hline ChangLe (CL) & Shaanxi & $X_{i}^{\prime} a n$ & $34^{\circ} 16^{\prime} 04^{\prime \prime} \mathrm{N}$ & $109^{\circ} 00^{\prime} 00^{\prime \prime} \mathrm{E}$ & 24.7 & $2.2 \times 10^{5}$ & $8.8 \times 10^{6}$ & 1956 \\
\hline XiangShan (XS) & Henan & Xinyang & $31^{\circ} 34^{\prime} 27^{\prime \prime} \mathrm{N}$ & $114^{\circ} 55^{\prime} 00^{\prime \prime} \mathrm{E}$ & 26.0 & $1.1 \times 10^{7}$ & $6.4 \times 10^{6}$ & 1969 \\
\hline $\mathrm{AiXi}(\mathrm{AX})$ & Jiangxi & Nanchang & $28^{\circ} 42^{\prime} 56^{\prime \prime} \mathrm{N}$ & $115^{\circ} 59^{\prime} 21^{\prime \prime} \mathrm{E}$ & 29.7 & $4.5 \times 10^{6}$ & $5.5 \times 10^{7}$ & 2007 \\
\hline HuiLongShan (HLS) & Jiangsu & Zhenjiang & $32^{\circ} 09^{\prime} 24^{\prime \prime} \mathrm{N}$ & $119^{\circ} 27^{\prime} 07^{\prime \prime} \mathrm{E}$ & 22.0 & $1.3 \times 10^{7}$ & $3.1 \times 10^{6}$ & 1977 \\
\hline GaoTie (GT) & Jiangsu & Changzhou & $31^{\circ} 51^{\prime} 21^{\prime \prime} \mathrm{N}$ & $119^{\circ} 58^{\prime} 07^{\prime \prime} \mathrm{E}$ & 26.3 & $1.0 \times 10^{5}$ & $3.8 \times 10^{6}$ & 2017 \\
\hline JinSha (JS) & Zhejiang & Hangzhou & $30^{\circ} 18^{\prime} 52^{\prime \prime} \mathrm{N}$ & $120^{\circ} 20^{\prime} 00^{\prime \prime} \mathrm{E}$ & 28.3 & $3.1 \times 10^{4}$ & $9.2 \times 10^{6}$ & 2018 \\
\hline XiLiu (XL) & Henan & Zhengzhou & $34^{\circ} 46^{\prime} 00^{\prime \prime} \mathrm{N}$ & $113^{\circ} 34^{\prime} 36^{\prime \prime} \mathrm{E}$ & 28.7 & $4.6 \times 10^{8}$ & $1.1 \times 10^{7}$ & 2012 \\
\hline ZiZhuYuan (ZZY) & Beijing & Beijing & $39^{\circ} 56^{\prime} 48^{\prime \prime} \mathrm{N}$ & $116^{\circ} 19^{\prime} 04^{\prime \prime} \mathrm{E}$ & 23.3 & $1.9 \times 10^{5}$ & $2.2 \times 10^{7}$ & 1953 \\
\hline GuiLong (GL) & Yunnan & Kunming & $25^{\circ} 04^{\prime} 10^{\prime \prime} \mathrm{N}$ & $102^{\circ} 42^{\prime} 53^{\prime \prime} \mathrm{E}$ & 24.0 & $1.6 \times 10^{5}$ & $6.7 \times 10^{6}$ & 2006 \\
\hline ZhuZhai (ZZ) & Shanghai & Shanghai & $31^{\circ} 12^{\prime} 53^{\prime \prime} \mathrm{N}$ & $121^{\circ} 17^{\prime} 36^{\prime \prime} \mathrm{E}$ & 27.3 & $3.5 \times 10^{4}$ & $1.4 \times 10^{7}$ & 2004 \\
\hline ZhongShan (ZS) & Shenzhen & Shenzhen & $31^{\circ} 13^{\prime} 27^{\prime \prime} \mathrm{N}$ & $121^{\circ} 25^{\prime} 23^{\prime \prime} \mathrm{E}$ & 33.3 & $3.5 \times 10^{4}$ & $1.1 \times 10^{7}$ & 2004 \\
\hline West lake (WL) & Zhejiang & Hangzhou & $30^{\circ} 13^{\prime} 14^{\prime \prime} \mathrm{N}$ & $120^{\circ} 06^{\prime} 30^{\prime \prime} \mathrm{E}$ & 29.0 & $6.4 \times 10^{6}$ & $9.2 \times 10^{6}$ & Qin and Han Dynasties \\
\hline Yunv (YN) & Sichuan & Mianyang & $31^{\circ} 29^{\prime} 54^{\prime \prime} \mathrm{N}$ & $104^{\circ} 44^{\prime} 14^{\prime \prime} \mathrm{E}$ & 25.3 & $2.4 \times 10^{5}$ & $5.4 \times 10^{6}$ & 1986 \\
\hline
\end{tabular}




\subsection{Water Physicochemical Analysis}

To determine the water quality parameters, the $\mathrm{pH}$, nitrite nitrogen $\left(\mathrm{NO}_{2}{ }^{-}-\mathrm{N}\right)$, nitrate nitrogen $\left(\mathrm{NO}_{3}{ }^{-} \mathrm{N}\right)$, ammonia nitrogen $\left(\mathrm{NH}_{4}{ }^{+}-\mathrm{N}\right)$, total nitrogen $(\mathrm{TN})$, total phosphorus (TP), total organic carbon (TOC), permanganate index $\left(\mathrm{COD}_{\mathrm{Mn}}\right), \mathrm{Fe}$, and $\mathrm{Mn}$ concentrations were measured. The $\mathrm{pH}$ was measured using a $\mathrm{pH}$ meter (Hach, USA) in the field. $\mathrm{NO}_{2}{ }^{-}-\mathrm{N}, \mathrm{NO}_{3}{ }^{-}-\mathrm{N}, \mathrm{NH}_{4}{ }^{+}-\mathrm{N}$, and TN concentrations were determined using a flow injection analyzer (FIA) (Seal Analytical AA3, Norderstedt, Germany) based on a previously described method [35]. TP was measured using a spectrophotometer (DR6000, Hach, USA). TOC was measured using a TOC analyzer (TOC-L CPN, Japan). COD Mn was examined using a spectrophotometer (UV-mini 1240, Shimadzu, Japan) [36,37]. Fe and Mn concentrations were measured using Inductively Coupled Plasma Mass Spectrometry (ICP-MS).

\subsection{Algal Cell Concentration and Community}

To measure the algal cell concentration, $500 \mathrm{~mL}$ of surface water samples through $0.45 \mu \mathrm{m}$ polycarbonate membrane ( $47 \mathrm{~mm}$ diameter, Millipore, USA). The algae enriched on the $0.45 \mu \mathrm{m}$ polycarbonate membrane were concentrated to a final volume of $10 \mathrm{~mL}$, and $1 \%$ Lugol's iodine solution was added there. Algae were identified to the phyla/ genus level and counted using a microscope (Olympus BX51, Japan) following Shen et al. [38], Zhang et al. [39], and Hu et al. [40] and reported in terms of $\times 10^{4}$ cells per liter. To further demonstrate the variety of algal morphology, $100 \mu \mathrm{L}$ of algae fluid was fixed by the above method, dropped on a glass slide, a picture was taken under a 400 $\times$ microscope (50I, Nikon, Japan). Typical algal pictures were selected for display in this study. The assays were performed in triplicate.

\subsection{Network Construction}

The integrated network was generated using a visualized Gephi platform (version 0.9.2) based on samples from 16 different urban lakes, which was constructed for strong $(r \geq|0.6|)$ and statistically significant $(p$-value $<0.05)$ correlations incorporated into network analyses [41,42]. A total of 52 identified genera of algae and 10 environmental factors $\left(\mathrm{pH}, \mathrm{TN}, \mathrm{NO}_{3}{ }^{-}-\mathrm{N}, \mathrm{NO}_{2}{ }^{-}-\mathrm{N}, \mathrm{NH}_{4}{ }^{+}-\mathrm{N}, \mathrm{TP}, \mathrm{TOC}\right.$, $\mathrm{COD}_{\mathrm{Mn}}, \mathrm{Fe}, \mathrm{Mn}$ ) were included in the networks. For modular analysis, gephi employed the Louvain method developed by Blondel et al. [43]. For modular analysis, the size and color of the nodes indicate the number of samples and classification, respectively. The thickness and color of the line connecting two nodes (i.e., edge) represent the Spearman's correlation coefficient $(r)$ and the positive or negative correlation, respectively. Gephi was also applied to determine node-level topology properties (i.e., degree, betweenness, and closeness centralities). Degree centrality is the number of directly connected nodes. Betweenness centrality refers to the number of shortest paths going through a node. Closeness centralities are the sum of the shortest distances from one node to other nodes [44]. Many topological parameters (e.g., the number of nodes and edges, average path length, network diameter, average degree, graph density, clustering coefficient, and modularity index) were calculated using the igraph package in $\mathrm{R}$ [45].

\subsection{Statistical Analysis}

To compare the mean value of water quality parameters and algal cell concentration in different urban lakes, statistical analyses were performed using one-way factorial analysis of variance (ANOVA) followed by a Tukey HSD post-hoctest using SPSS (version 17.0, SPSS Inc, Chicago, IL, USA). The distribution of algae at the phyla level in 16 different urban lakes was visualized by using Circos (version 0.69, http://circos.ca/). Heat map profiles were performed using R software to compare the algal community structure at the genus level(version 3.2.3) [46]. A correspondence analysis revealed that the length of the first axis was less than three [47]. The interrelation between the water quality and water algal communities of different urban lake samples were measured using multivariate correlation analysis (redundancy analysis, RDA), which was performed using the Canoco software package for 
Windows (version 4.5) (Ithaca, New York, USA) with Monte Carlo permutation tests (999 permutations). The graphics were generated in Cano Draw (version 3.10) for Windows [47].

\section{Results and Discussion}

\subsection{Water Quality Parameters}

The geographic locations of the studied urban lakes are summarized in Table 1 . All of the 16 different urban lakes physical parameters $(\mathrm{pH})$ and nutrient concentrations (e.g., $\mathrm{TP}, \mathrm{TN}, \mathrm{NO}_{3}{ }^{-}-\mathrm{N}$, $\mathrm{NO}_{2}{ }^{-}-\mathrm{N}, \mathrm{NH}_{4}{ }^{+}-\mathrm{N}, \mathrm{TOC}, \mathrm{COD}_{\mathrm{Mn}}, \mathrm{Fe}$, and $\mathrm{Mn}$ ) are summarized in Table 2. Water quality characteristics were distinct among the different urban lakes' geographical locations. The $\mathrm{pH}$ values ranged from 7.27 in GL lake to 9.30 in TX lake ( $F=94.319, p<0.001)$. The highest TP $(0.21 \mathrm{mg} / \mathrm{L}), \mathrm{NO}_{3}{ }^{-}-\mathrm{N}(0.39 \mathrm{mg} / \mathrm{L})$, and $\mathrm{TN}(3.84 \mathrm{mg} / \mathrm{L})$ concentrations were found in XHH lake $(F=2106.073, p<0.001 ; F=501.578, p<0.001$; $F=1138.293, p<0.001)$, it also showed highest the TOC and COD Mn concentrations among the samples. The lowest TOC $(1.09 \mathrm{mg} / \mathrm{L})$ concentrations were observed in CL lake $(F=270.402, p<0.001)$. The $\mathrm{NH}_{4}{ }^{+}-\mathrm{N}$ concentrations varied from 0.01 to $0.50 \mathrm{mg} / \mathrm{L}(F=452.529, p<0.001)$. The COD $\mathrm{Mn}$ concentration ranged from 4.21 in GT lake to 9.01 in XHH lake $(F=114.866, p<0.001)$. It is worth noting that the Fe and Mn concentrations were low in all urban lakes $(F=22.044, p<0.001 ; F=6.267, p<0.001)$. In addition, both JS lake and WL lakes are located in Hangzhou, but the TN concentrations in JS lake was approximately two times higher than that of WL lake. Similarly, Yang et al. [48] found that the 16 urban water sampling points $\mathrm{pH}$ values were between 6.9 and 9.8 in western China, and the distance between the sampling lakes was $9-2027 \mathrm{~km}$. In addition, a large number of previous studies have shown that spatial distance can create spatial differences in water quality characteristics [49]. XXH lake is the largest wetland park in the northern part of Shizuishan, where the area and ecological environment are exposed to human activities and industrial and agricultural development. Human activities are bound to cause pollution of urban water bodies, and a large amount of domestic garbage and heavy metals enter the water bodies directly or through release of sediment indirectly. Xiong et al. [49] suggested that human activities and climate change affect water quality in two agricultural catchments in Finland, the result is consistent with this study. Furthermore, XXH lake is composed of lake wetlands, barren sandy land, fishing ponds, and farmland. There are three pulverized coal plants around the lake, which are the main pollution sources of XXH lake. Aquaculture and agricultural wastewater cause a large amount of nitrogen and phosphorus nutrients to be input into wetland water bodies $[50,51]$. In addition, the surface of fly ash contains a certain amount of adsorbed nitrate nitrogen which further aggravates the accumulation of nitrogen in water bodies. Previous research reported that only $20 \%-25 \%$ of the protein in the feed was generally absorbed by fish, and most of the rest was discharged to the water body in the form of ammonia or organic nitrogen, causing eutrophication of the surrounding water bodies [52,53]. The pollution of agricultural wastewater mainly comes from abuse of organic fertilizer by farmers. Green et al. [54] stated that due to the long-term transport of $\mathrm{N}$ elements caused by the large amount of fertilizer input in the corn planting area, the nitrate and nitrite content of the water body in Edwards changed significantly. Another important reason for the high nitrogen content in the water body of XHH lake was that nitrogen adsorbed on the surface of fly ash accumulated in the fly ash plant for a long time and entered the water body under the wash of rainwater [55]. WL lake is located in the middle of Hangzhou, Zhejiang Province, and is a famous urban tourist lake in China. After 1960, the massive discharge of urban sewage led to the eutrophication of the West Lake intensively. In 2002 and 2006, Hangzhou city launched the West Lake Westward Project and the aquatic vegetation ecological restoration project, respectively. The water nutrient status gradually changed from eutrophic to medium nutrient level. The result showed that water quality of urban lakes is different, when it has similar locations and climatic conditions. Historical environment changes and human disturbances can also affect the water environment. Andersson et al. [56] also concluded that the spatial difference of urban lakes water quality is affected by environmental conditions and historical events. Moreover, Jiang et al. [17] found that the concentrations of $\mathrm{PO}_{4}{ }^{3-}-\mathrm{P}, \mathrm{TP}, \mathrm{NH}_{4}{ }^{+}-\mathrm{N}$, 
and $\mathrm{NO}_{2}{ }^{-}-\mathrm{N}$ in western rivers around Lake Chaohu were much higher than those in other samples of lake Chaohu. Simultaneously, Shang et al. [57] found that the eutrophication state of the lake Chaohu western part is more serious than that of the eastern part, mainly because the former is the final place of industrial and municipal wastewater from Hefei City, the capital of Anhui province. Therefore, the water quality of urban lakes may be affected by geographical environment factors, industrial and agricultural wastewater, human activity, and historical environment changes.

\subsection{Algal Cell Concentration}

In the present study, we investigated the algal cell concentrations in 16 urban lakes, collected at various sites from different regions of north, central, south, and coastal economic zones in China (Figure 2). The algal cell concentration was high in XXH lake $\left(247,800 \times 10^{4}\right.$ cell/L) and ZS lake $\left(206,300 \times 10^{4} \mathrm{cell} / \mathrm{L}\right)$. These values were much higher than other sample sites. XXH lake is located in Dawukou district, Shizuishan City, a newly developed industrial city in Yinbei. With the development of urbanization, human domestic waste, domestic sewage, and industrial wastewater in cities and towns, flow into surface water in the form of surface runoff. High input of nutrients such as nitrogen and phosphorus caused an algae outbreak in $\mathrm{XHH}$ lake, previous numerous reports also support this point of view [58]. In addition, nutrient enrichment facilitates algal outbreaks in eutrophic shallow lakes. The $\mathrm{N}$ plus $\mathrm{P}$ amendment promoted higher biomass of the planktonic microbial community, and the dual addition of $\mathrm{NH}_{4}{ }^{+}+\mathrm{PO}_{4}$ yielded the highest chlorophyll a concentration, as found by Dodd in other freshwater lakes [18]. Compared with $\mathrm{XHH}$ lake, the concentration of nitrogen and phosphorus in ZS lake is relatively low, but ZS lake is located in Shenzhen, which has a subtropical maritime climate with warm and humid seasons, abundant rain, and abundant sunshine. Temperature has a certain influence on the abundance and biomass of algae. When the water temperature reaches the optimum temperature for algal growth, the primary productivity begins to rise rapidly. The conclusion is consistent with Huber's findings; Huber et al. [59] suggested that nutrient loading and winter temperature influence the timing of the phytoplankton spring bloom. The concentration of algal cells in the urban lakes of JS lake $\left(52,700 \times 10^{4} \mathrm{cell} / \mathrm{L}\right), \mathrm{WL}\left(47,500 \times 10^{4} \mathrm{cell} / \mathrm{L}\right)$, GT lake $\left(165,400 \times 10^{4} \mathrm{cell} / \mathrm{L}\right)$, HLS lake $\left(92,400 \times 10^{4} \mathrm{cell} / \mathrm{L}\right)$, and ZZ lake $\left(6300 \times 10^{4} \mathrm{cell} / \mathrm{L}\right)$ are relatively high. Those five urban lakes are located in the Jiangsu, Zhejiang, and Shanghai regions in the eastern Yangtze River Delta of China. Jiangsu, Zhejiang, and Shanghai are in a subtropical monsoon climate with abundant sunshine and rainfall. There are strong storms and rains in these coastal areas during the summer. Rainfall can dilute pollutants in urban waters, but also carry nutrients into the water. Heavy rain increased the nutrient content and further affected the algal outbreak in the water body. Similarly, Greenaway et al. [60] investigatedthe effects of groundwater and rainfall on the ambient concentrations of inorganic nitrogen and phosphorus in the coastal waters of Discovery Bay, Jamaica. The results documented that heavy, widespread rainfall events significantly increased the concentration of $\mathrm{NO}_{3}{ }^{-}-\mathrm{N}$, and in severe cases elevated $\mathrm{NO}_{3}{ }^{-}-\mathrm{N}$ concentrations were sustained for several months. Based on the above comparative analysis, we found that the biomass of algae reveals a contrast change on a spatial scale (Figure 2). Nutrition, rainfall, and temperature are the main factors that cause significant differences in algal cell concentration in different urban lakes. 
Table 2. Quality parameters associated with 16 different geographically distributed urban lakes, China.

\begin{tabular}{|c|c|c|c|c|c|c|c|c|c|c|}
\hline \multirow{2}{*}{ Urban Lakes } & \multirow{2}{*}{$\mathrm{pH}$} & TN & $\mathrm{NO}_{3}{ }^{-}-\mathrm{N}$ & $\mathrm{NO}_{2}=\mathrm{N}$ & $\mathrm{NH}_{4}{ }^{+}-\mathrm{N}$ & TP & $\operatorname{COD}_{M n}$ & $\mathrm{Fe}$ & Mn & TOC \\
\hline & & \multicolumn{9}{|c|}{$(\mathrm{mg} / \mathrm{L})$} \\
\hline TieXi (TX) & $9.30 \pm 0.24 a$ & $0.44 \pm 0.061$ & $0.07 \pm 0.01$ ef & $0.01 \pm 0.00 \mathrm{~b}$ & $0.03 \pm 0.00 \mathrm{j}$ & $0.01 \pm 0.00 \mathrm{~h}$ & $5.79 \pm 0.87 \mathrm{c}$ & $0.03 \pm 0.00 \mathrm{bcd}$ & $0.01 \pm 0.00 \mathrm{bc}$ & $5.74 \pm 0.28 \mathrm{bc}$ \\
\hline XinHaiHu (XHH) & $8.48 \pm 0.06 \mathrm{~b}$ & $3.84 \pm 0.33 \mathrm{a}$ & $0.39 \pm 0.09 a$ & $0.04 \pm 0.03 \mathrm{a}$ & $0.30 \pm 0.05 \mathrm{c}$ & $0.21 \pm 0.01 \mathrm{a}$ & $9.01 \pm 0.31 \mathrm{a}$ & $0.02 \pm 0.00 \mathrm{de}$ & $0.01 \pm 0.00 \mathrm{a}$ & $9.77 \pm 0.71 \mathrm{a}$ \\
\hline JinJi (JJ) & $8.04 \pm 0.14 \mathrm{de}$ & $0.85 \pm 0.26 \mathrm{gh}$ & $0.06 \pm 0.01 \mathrm{fg}$ & $0.01 \pm 0.00 \mathrm{~b}$ & $0.15 \pm 0.07 \mathrm{ef}$ & $0.05 \pm 0.00 \mathrm{~cd}$ & $5.08 \pm 0.10 \mathrm{de}$ & $0.04 \pm 0.01 \mathrm{bc}$ & $0.01 \pm 0.00 \mathrm{a}$ & $5.69 \pm 0.56 \mathrm{~d}$ \\
\hline ChangLe (CL) & $7.72 \pm 0.43 \mathrm{de}$ & $0.57 \pm 0.11 \mathrm{jk}$ & $0.04 \pm 0.01 \mathrm{fg}$ & $0.04 \pm 0.01 \mathrm{a}$ & $0.10 \pm 0.00 \mathrm{ghi}$ & $0.06 \pm 0.00 \mathrm{~b}$ & $4.70 \pm 1.44 \mathrm{f}$ & $0.04 \pm 0.01 \mathrm{a}$ & $0.00 \pm 0.00 c$ & $1.09 \pm 0.20 \mathrm{f}$ \\
\hline XiangShan (XS) & $7.45 \pm 0.04 \mathrm{gh}$ & $1.02 \pm 0.07 \mathrm{~g}$ & $0.16 \pm 0.03 c$ & $0.01 \pm 0.00 \mathrm{~b}$ & $0.01 \pm 0.00 \mathrm{j}$ & $0.02 \pm 0.00 \mathrm{~g}$ & $3.60 \pm 0.25 \mathrm{f}$ & $0.02 \pm 0.00 \mathrm{ef}$ & $0.01 \pm 0.00 \mathrm{ab}$ & $4.07 \pm 0.55 \mathrm{~d}$ \\
\hline $\mathrm{AiXi}(\mathrm{AX})$ & $7.40 \pm 0.09 \mathrm{gh}$ & $0.57 \pm 0.16 \mathrm{ij}$ & $0.12 \pm 0.03 \mathrm{~d}$ & $0.01 \pm 0.00 \mathrm{~b}$ & $0.13 \pm 0.07 \mathrm{e}$ & $0.03 \pm 0.01 \mathrm{f}$ & $5.13 \pm 0.86 \mathrm{~cd}$ & $0.04 \pm 0.012 \mathrm{ab}$ & $0.01 \pm 0.002 \mathrm{a}$ & $5.61 \pm 0.17 \mathrm{bc}$ \\
\hline HuiLongShan (HLS) & $7.88 \pm 0.10 \mathrm{def}$ & $0.52 \pm 0.02 \mathrm{f}$ & $0.06 \pm 0.01 \mathrm{fg}$ & $0.01 \pm 0.00 \mathrm{~b}$ & $0.07 \pm 0.01 \mathrm{f}$ & $0.03 \pm 0.01 \mathrm{~cd}$ & $4.43 \pm 0.18 \mathrm{ef}$ & $0.02 \pm 0.00 \mathrm{de}$ & $0.01 \pm 0.00 \mathrm{a}$ & $4.66 \pm 0.59 b$ \\
\hline GaoTie (GT) & $8.20 \pm 0.19 b c$ & $0.35 \pm 0.11 \mathrm{kl}$ & $0.04 \pm 0.02 \mathrm{fg}$ & $0.01 \pm 0.00 \mathrm{~b}$ & $0.07 \pm 0.01 \mathrm{i}$ & $0.05 \pm 0.01 \mathrm{ef}$ & $4.21 \pm 0.11 \mathrm{f}$ & $0.02 \pm 0.00 \mathrm{ef}$ & $0.01 \pm 0.00 \mathrm{a}$ & $3.78 \pm 0.54 a$ \\
\hline JinSha (JS) & $8.15 \pm 0.19 \mathrm{~cd}$ & $2.08 \pm 0.22 \mathrm{~m}$ & $0.04 \pm 0.00 \mathrm{fg}$ & $0.01 \pm 0.00 \mathrm{~b}$ & $0.15 \pm 0.03 \mathrm{hi}$ & $0.05 \pm 0.01 \mathrm{~cd}$ & $4.35 \pm 0.80 \mathrm{f}$ & $0.02 \pm 0.01 \mathrm{ef}$ & $0.01 \pm 0.00 \mathrm{a}$ & $9.33 \pm 0.45 a$ \\
\hline XiLiu (XL) & $7.79 \pm 0.02 \mathrm{ef}$ & $0.77 \pm 0.10 \mathrm{~b}$ & $0.37 \pm 0.06 \mathrm{~g}$ & $0.04 \pm 0.01 \mathrm{a}$ & $0.41 \pm 0.01 \mathrm{f}$ & $0.05 \pm 0.01 \mathrm{~cd}$ & $4.42 \pm 0.30 \mathrm{ef}$ & $0.02 \pm 0.00 \mathrm{de}$ & $0.01 \pm 0.00 \mathrm{a}$ & $3.34 \pm 0.19 b$ \\
\hline ZiZhuYuan (ZZY) & $7.95 \pm 0.02 \mathrm{de}$ & $0.32 \pm 0.03 \mathrm{hi}$ & $0.22 \pm 0.03 \mathrm{a}$ & $0.01 \pm 0.00 \mathrm{~b}$ & $0.11 \pm 0.01 \mathrm{~b}$ & $0.05 \pm 0.01 \mathrm{~cd}$ & $5.67 \pm 0.80 \mathrm{c}$ & $0.01 \pm 0.01 \mathrm{ef}$ & $0.01 \pm 0.00 \mathrm{a}$ & $3.17 \pm 0.62 \mathrm{e}$ \\
\hline GuiLong (GL) & $7.27 \pm 0.27 \mathrm{hi}$ & $1.23 \pm 0.40 \mathrm{~m}$ & $0.19 \pm 0.23 \mathrm{~b}$ & $0.01 \pm 0.00 \mathrm{~b}$ & $0.16 \pm 0.03 \mathrm{gh}$ & $0.05 \pm 0.00 \mathrm{~d}$ & $6.23 \pm 1.12 \mathrm{~cd}$ & $0.02 \pm 0.01 \mathrm{ced}$ & $0.01 \pm 0.00 \mathrm{a}$ & $5.77 \pm 0.26 \mathrm{~b}$ \\
\hline ZhuZhai (ZZ) & $7.28 \pm 0.30 \mathrm{i}$ & $0.70 \pm 0.06 \mathrm{ij}$ & $0.13 \pm 0.05 \mathrm{de}$ & $0.01 \pm 0.00 \mathrm{~b}$ & $0.01 \pm 0.00 \mathrm{j}$ & $0.03 \pm 0.01 \mathrm{ef}$ & $8.35 \pm 0.10 \mathrm{a}$ & $0.01 \pm 0.00$ efg & $0.01 \pm 0.002 \mathrm{a}$ & $4.76 \pm 0.14 \mathrm{~d}$ \\
\hline ZhongShan (ZS) & $7.45 \pm 0.03 \mathrm{gh}$ & $1.37 \pm 0.04 \mathrm{e}$ & $0.05 \pm 0.02 \mathrm{fg}$ & $0.01 \pm 0.00 \mathrm{~b}$ & $0.25 \pm 0.00 \mathrm{~d}$ & $0.05 \pm 0.00 \mathrm{~cd}$ & $7.1 \pm 0.27 \mathrm{~b}$ & $0.02 \pm 0.00 \mathrm{ef}$ & $0.01 \pm 0.002 \mathrm{a}$ & $4.31 \pm 0.41 \mathrm{e}$ \\
\hline West Lake (WL) & $7.94 \pm 0.04 \mathrm{de}$ & $1.05 \pm 0.47 \mathrm{~d}$ & $0.15 \pm 0.03 \mathrm{~cd}$ & $0.01 \pm 0.00 \mathrm{~b}$ & $0.11 \pm 0.01 \mathrm{~g}$ & $0.04 \pm 0.00 \mathrm{e}$ & $4.41 \pm 0.81 \mathrm{f}$ & $0.00 \pm 0.00 \mathrm{fg}$ & $0.01 \pm 0.000 \mathrm{a}$ & $2.82 \pm 0.49 \mathrm{e}$ \\
\hline YuNv (YN) & $7.61 \pm 0.05 \mathrm{fg}$ & $2.08 \pm 0.10 \mathrm{c}$ & $0.11 \pm 0.01 \mathrm{de}$ & $0.10 \pm 0.00 \mathrm{~b}$ & $0.50 \pm 0.04 \mathrm{a}$ & $0.06 \pm 0.01 \mathrm{~b}$ & $8.33 \pm 0.08 \mathrm{a}$ & $0.00 \pm 0.00 \mathrm{~g}$ & $0.01 \pm 0.002 \mathrm{a}$ & $5.59 \pm 0.86 \mathrm{~b}$ \\
\hline One-way ANOVA & $* * *$ & $* * *$ & $* * *$ & $* * *$ & $* * *$ & $* * *$ & $* * *$ & $* * *$ & $* * *$ & $* * *$ \\
\hline
\end{tabular}

Values shown as means and standard deviations $(n=3)$. Different capital letter represents statistical significance. ${ }^{*} p<0.05,{ }^{* *} p<0.01$, and ${ }^{* * *} p<0.001$ represent statistical significance using one-way ANOVA followed by a post hoc Tukey's honestly significant difference (HSD) test. 


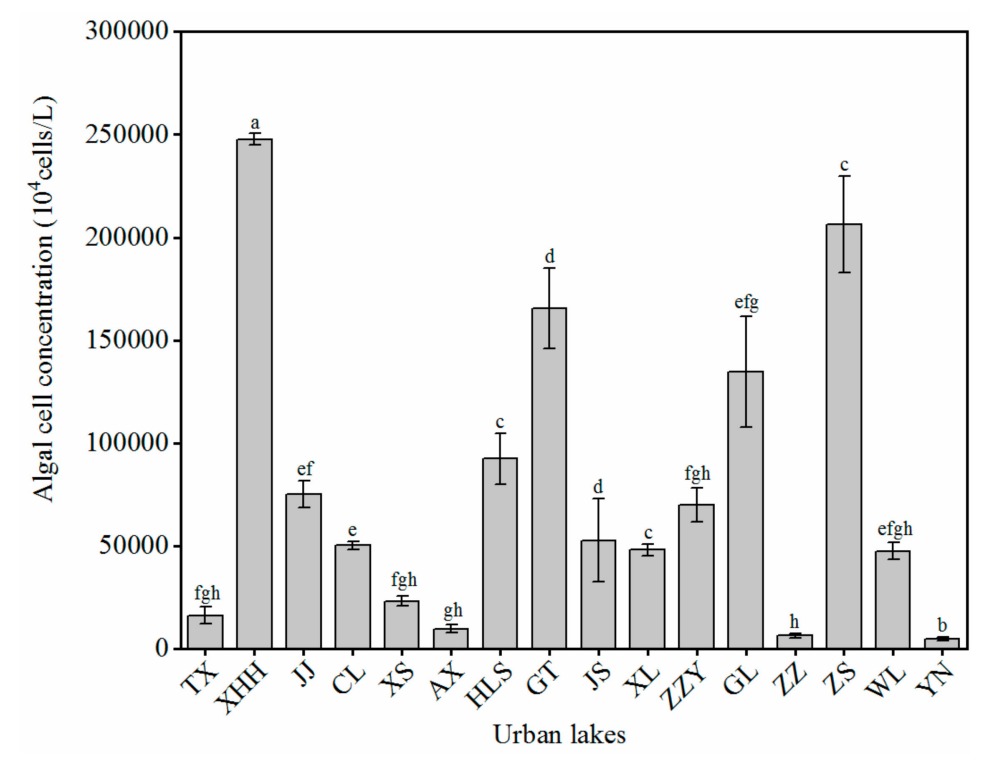

Figure 2. Algal cell concentration of 16 different urban lakes in October 2018. Bars with different upper letters are significantly different at 0.01 levels. Error bars represent standard deviations $(n=3)$.

\subsection{Geographical Patterns of Algal Community Composition and Typical Cell Morphology}

A total of six phyla were identified from 16 urban lakes, with qualitative and quantitative identification of algae including Chlorophyta, Bacillariophyta, Cyanophyta, Dinophyta, Euglenophyta, and Cryptophyta. Across all samples from 16 urban lakes, half of the urban lakes were dominated by Bacillariophyta (accounting for $88.3 \%$ in XHH lake, $76.8 \%$ in XL lake,71.2\% in JS lake,65.0\% in AX lake, $56.6 \%$ in JJ lake, $54.9 \%$ in TX lake, $53.3 \%$ in XS lake, $43.4 \%$ in ZZY lake, and $47.1 \%$ in HLS lake), followed by Cyanophyta (accounting for $82.4 \%$ in GLlake,53.3\% in GTlake, 51.3\% in YN lake, $43.1 \%$ in ZZ lake, $43.0 \%$ in WL),last by Chlorophyta (accounting for $37.2 \%$ in CLlake, and $44.3 \%$ in ZS lake) (Figure 3). Similar to our conclusion, Yang et al. [61] previously investigated the algal community characteristics by optical microscopy of 11 typical subtropical reservoirs in southeast Fujian, the result revealed that algal communities varied strongly across study reservoirs and the dominant phyla were Chlorophyta, Cyanophyta, Bacillariophyta, and Chrysophyta, which accounted for $92.01 \%$ of the mean relative abundance. These studies indicate that the algal community is affected by the local environment and geographical distribution, and which are the inherent physiological factors.

To further establish a detailed view on the algal community, as shown in Figure 4, a heat map profile with the total 63 algal community composition at the genus levels was drawn. Generally, the heat map indicated that algal communities in each urban lake were unique, and revealed that the algal communities in 16 urban lakes were more diverse and different. Some common algal morphologies during algae outbreaks are shown in Figure 5. For instance, Limnothrix sp. were the dominant genera in GL lake (29\%), XS lake (20\%), ZZY lake (23\%), GL lake (77\%), ZZ lake (35\%), WL lake (25\%), and YN lake (44\%), Synedra sp. were the dominant genera in JS lake (64\%), TX lake (22\%), and XL lake $(61 \%)$, Cyclotella sp. were the dominant genera in XXH lake (86\%), JJ lake (32\%), and AX lake (19\%), Nephrocytium sp., Melosira sp., and Scenedesmus sp. were the dominant genera in CLlake (25\%), AX lake $(19 \%)$, and ZS lake (27\%), respectively. Notably, GT lake and WL lake were the abundant genera in all samples. In the algal ecological classification, the above dominant algal species belong to Cyanophyta, Bacillariophyta, and Chlorophyta. Similar studies have suggested that the superiority of the genus Limnothrix sp. in Lake Kastoria, at the same time, high population densities over the winter and before the development of daphnia may be the main reason [62,63]. Besides, numerous previous studies have reported that algal bloom may be strongly correlated with Cyanobacteria, which was one of the most visible symptoms of eutrophication, particularly in warm, dry summers [63-65]. Synedra sp. is usually the dominant genus in the low temperature season [66,67]. For example, Bracht et al. [68] 
studied diatom deposits in Lake Crevice, Yellowstone National Park, USA, and found that in the long and cold spring, Synedra sp. was one of the dominant diatoms in the sediment. Cyclotella, one of the common diatoms in fresh water, is also the dominant algal species that cause algal blooms [69]. More importantly, we found that the spatial patterns were not only closely related climate environment but also to algal community structure characteristics.

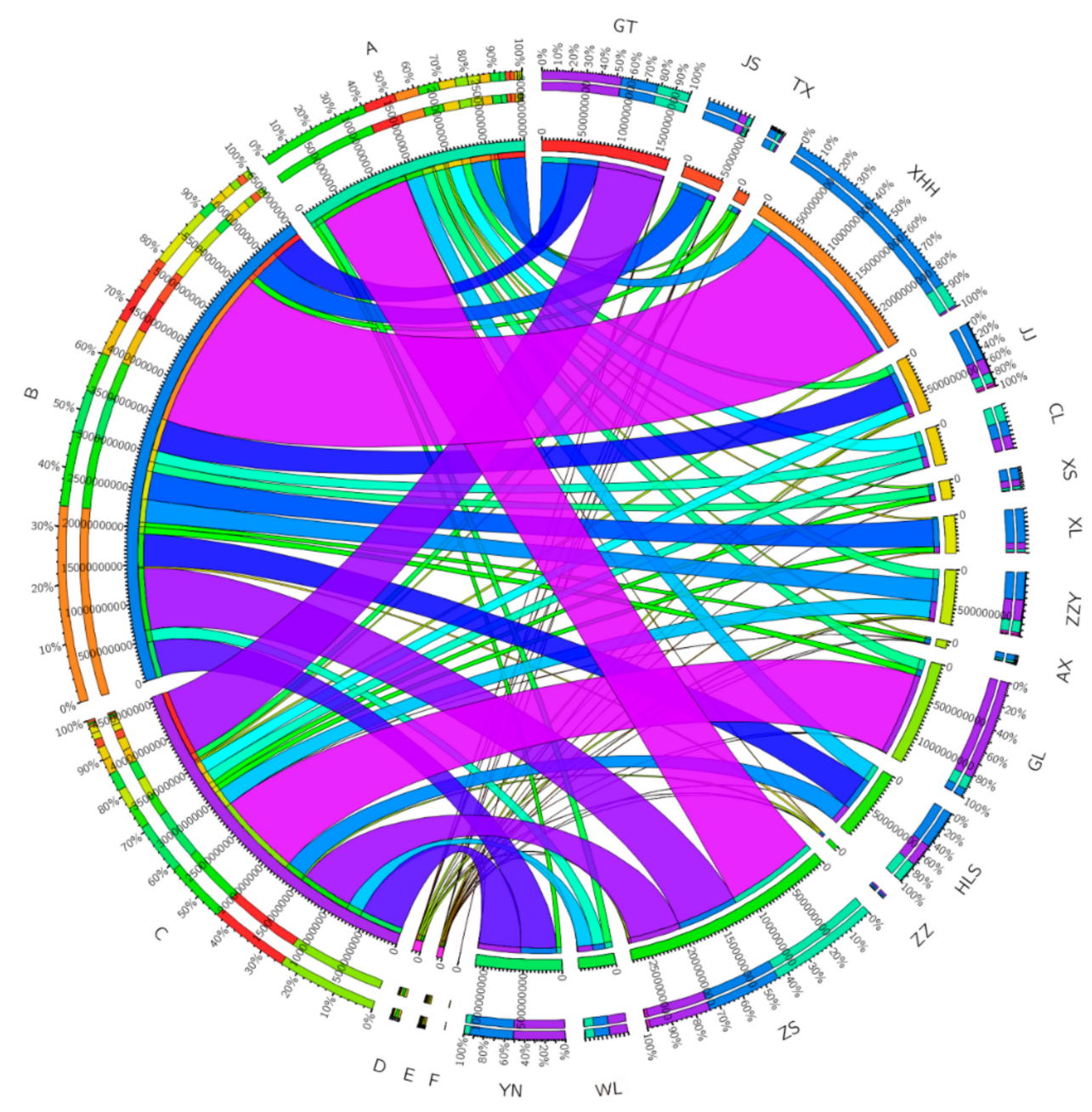

Figure 3. Circos representation of algal community at phyla level. The bands in the same urban lakes with different colors demonstratethe source of different phyla. (A) Chlorophyta, (B) Bacillariophyta, (C) Cyanophyta, (D) Dinophyta, (E) Euglenophyta, (F) Cryptophyta. The data were visualized via Circos software (http://circos.ca/).

\subsection{Co-Occurrence Network of Algae}

The co-occurring network has been successfully applied to infer microbial co-occurrence patterns in soil microbial communities [70], bacterial wastewater treatment plants [34], urban lakes denitrifying bacteria [71], and subtropical reservoirs eukaryotic plankton [28]. In this study, an integrated network was used to explore modular associations between algal taxa (i.e., abundant genera) and environmental factors in 16 geographically distributed urban lakes (see Figure 6 and Supplementary Materials), additionally, the properties of the integrated networks are summarized in Table 3. The integrated network is comprised of 62 nodes and 108 edges, with an average number of clustering coefficient of 0.209 and path length of 3.231. Meanwhile, all nodes in the network can be divided into five main modules, which accounted for $95.8 \%$ of the whole networks. Among the 10 water quality parameters of module $\mathrm{V}$, the two parameters of $\mathrm{NO}_{3}{ }^{-}-\mathrm{N}$ and $\mathrm{NH}_{4}{ }^{+}-\mathrm{N}$ are worthy of attention. $\mathrm{NO}_{3}{ }^{-}-\mathrm{N}$ and $\mathrm{NH}_{4}{ }^{+}-\mathrm{N}$ are associated with the largest number of nodes and mainly negatively and positively correlated with 
other nodes, respectively. Our results indicated that the algae biomass cycle in 16different urban lakes were strongly correlated with the algal community composition compared to other physical and chemical factors. However, the physical and chemical factors were significantly correlated with the algae biomass, and could indirectly influence the algal community composition [72]. Co-occurrence correlation analysis shows that the algal species are predominantly positive correlations. This suggests that mature microbial communities, niche separation, and less competition between algal species exist in the urban lakes. Algae species had the highest centrality values, which indicate their important role in the algal community. By analyzing the network, we found that keystone species belonged to Fragilaria sp., Scenedesmus sp., and Stephanodiscus sp., which as keystone taxa play an important role in maintaining network structure, compared with other taxa in the network [73]. Once keystone taxa disappear, the network may disassemble [28], keystone taxa play an important role in maintaining the stability of the ecosystem [74]. Therefore, co-occurrence network is a powerful technique for giving insights into the organization of algal communities and studying interactions that occur between algal communities, such as competition and resonance.

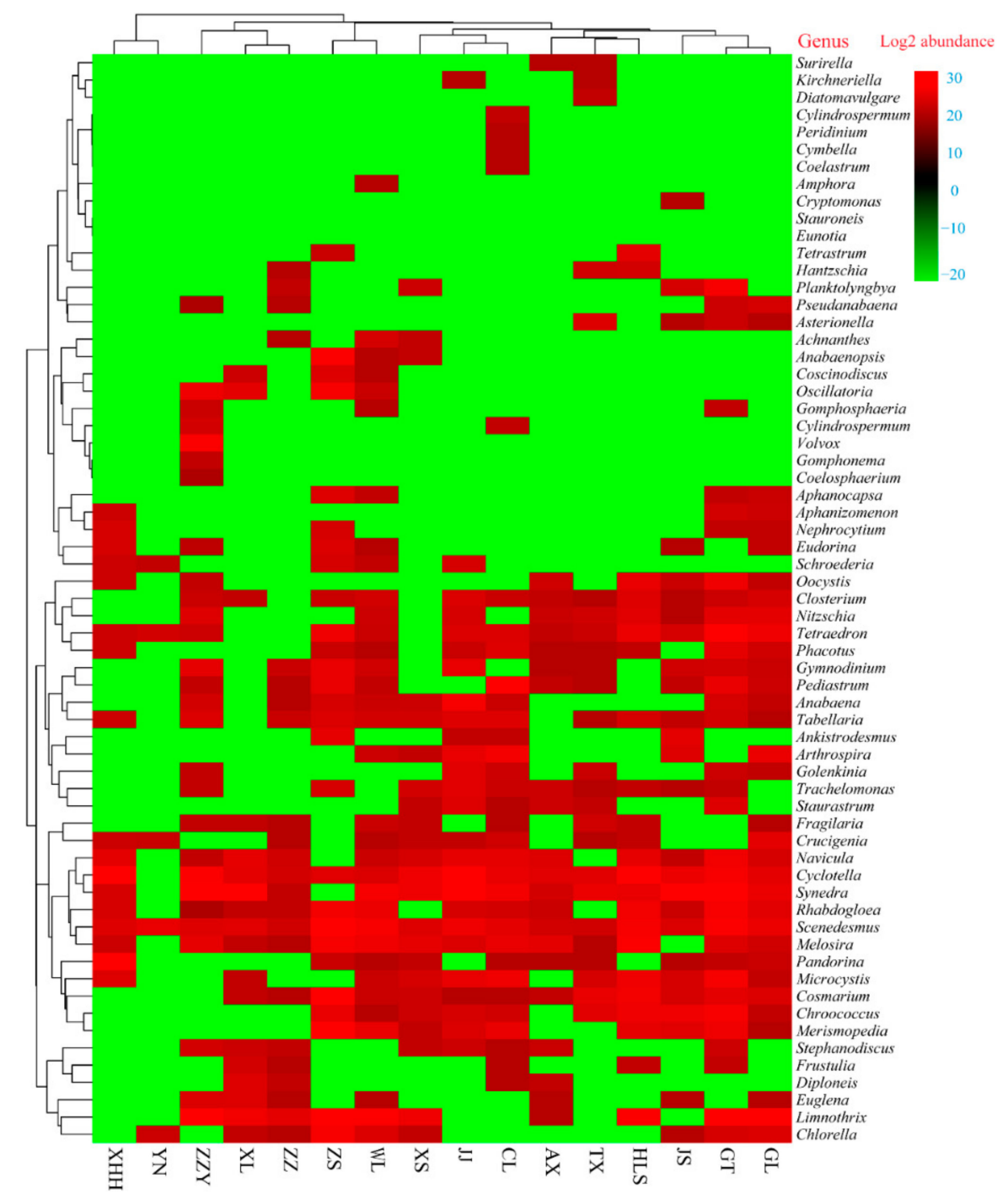

Figure 4. Heat map profile showing the algal community at the genus level in 16 different urban lakes. Green colors indicate lower abundance, red colors indicate higher abundance. GL, GT, JS, HLS, TX, AX, CL, JJ, XS, WL, ZS, ZZ, XL, ZZY, YN, and XHH represent GuiLong, GaoTie, JinSha, HuiLongShan, TieXi, AiXi, ChangLe, JinJi, XiangShan, WestLake, ZhongShan, ZhuZhai, XiLiu, ZiZhuYuan, YuNv, and XinHaiHu urban lakes, respectively. 


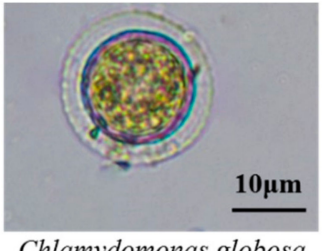

Chlamydomonas globosa

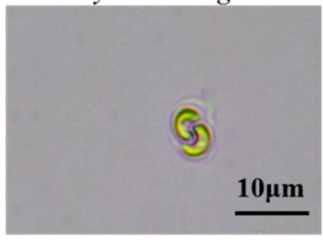

Nephrocytium sp.

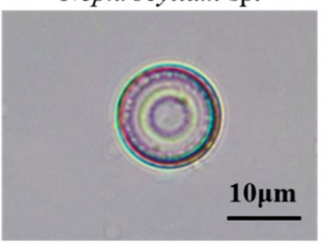

Cyclotella hubeiana

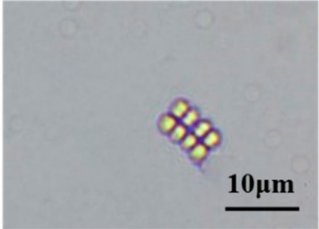

Merismopedia sp.



Cryptomonas sp.

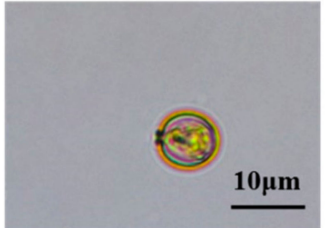

Trac helomonas sp.

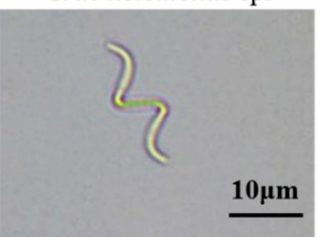

Raphidiopsis sinensia

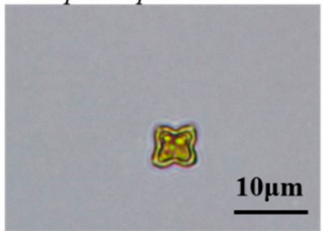

Tetraedron minimum



Botrydiopsis arhiza

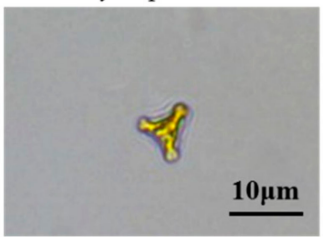

Tetradron trigonum

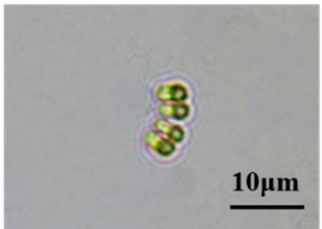

Scenedesmus arcuatus

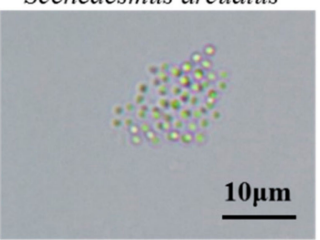

Microcystis sp.

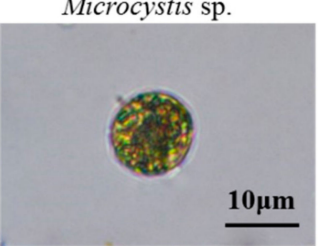

Trachelomonas sp.

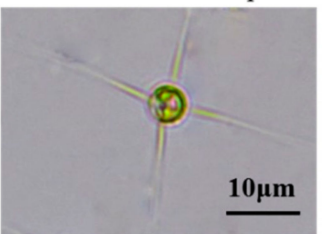

Chodate quadriseta

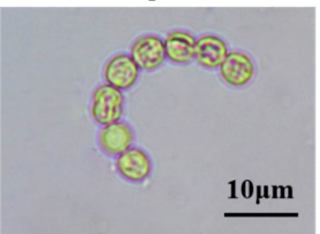

Pseudanabaena galeata

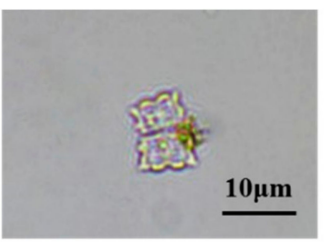

Euastrum denticulatum

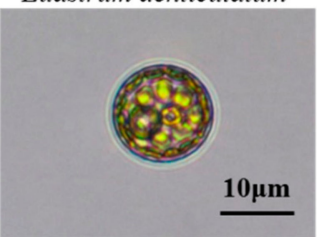

Cyclotella sp.

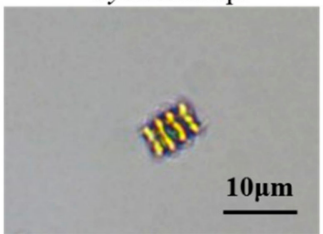

Scsnsdesmus armatus var

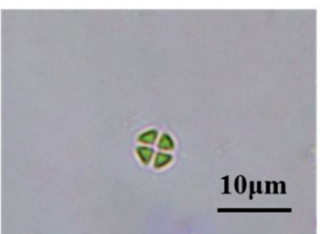

Crucigenia tetrapedia

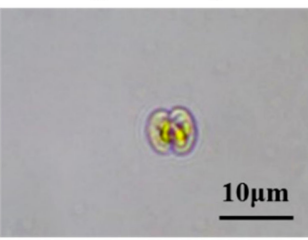

Cosmarium sp

Figure 5. Microscopic images of typical algae in 16 different urban lakes.

Table 3. The networks properties of algal communities at genus level.

\begin{tabular}{cc}
\hline Parameters & Number \\
\hline Avg. weighted degree & 0.548 \\
Network diameter & 7 \\
Graph density & 0.057 \\
Modularity & 1.446 \\
Connected components & 6 \\
Avg. clustering coefficient & 0.209 \\
Avg. path length & 3.231 \\
Nodes & 62 \\
Edges & 108 \\
\hline
\end{tabular}




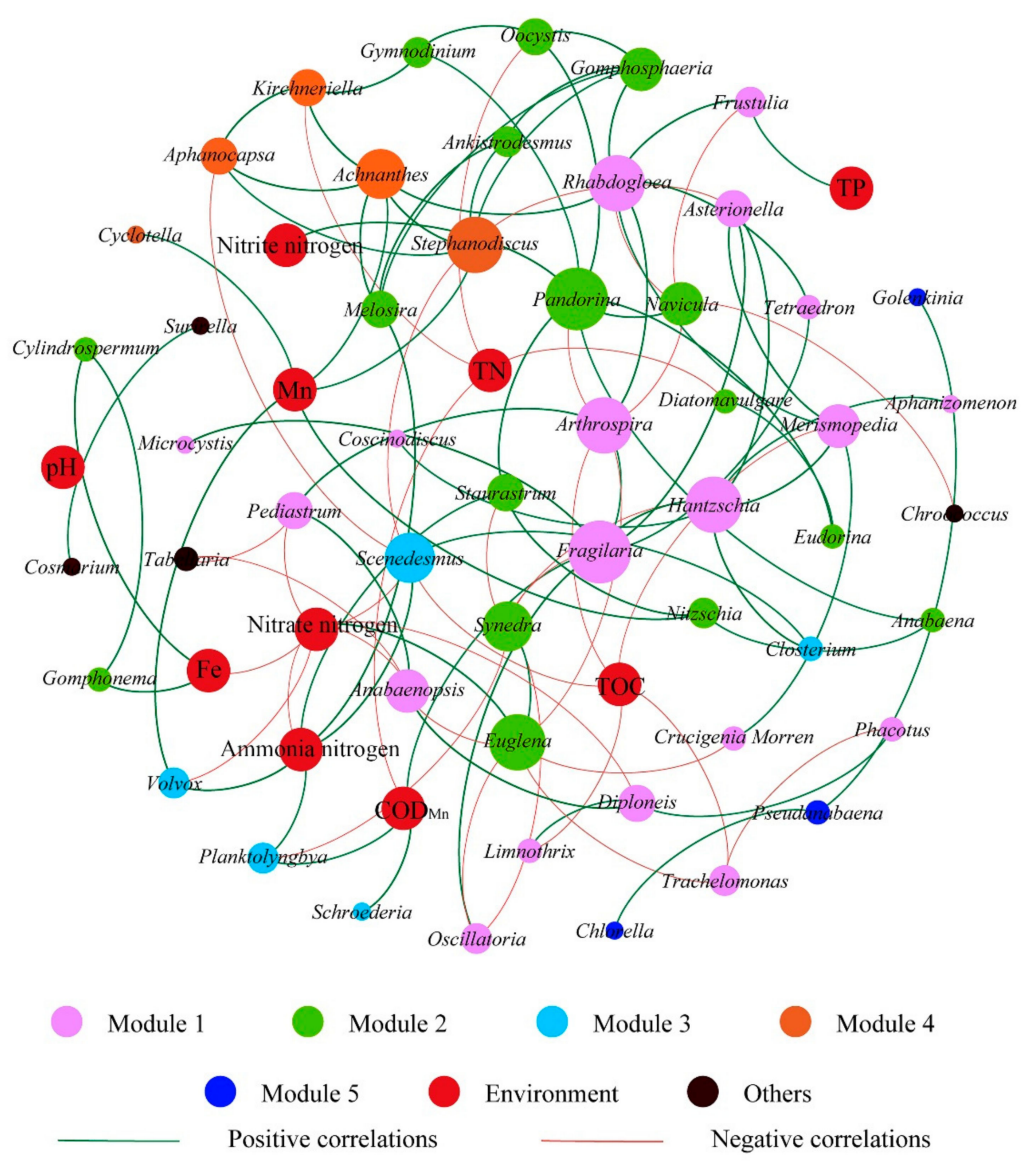

Figure 6. Network analysis revealing the modular associations between algal communities and environmental factors from 16 different urban lake samples. A connection stands for a strong (Spar CC $|r|>0.6)$ and significant ( $p$-value $<0.05$ ) correlation. The nodes are colored according to modularity class. The size of each node represents value of betweenness centrality.

\subsection{Relationship between Algal Communities and Water Quality}

To identify the relationship between algal communities of the different urban lakes and water parameters, redundancy analysis (RDA) which was consistent with the heat map was conducted. RDA1 andRDA2 explained $27.7 \%$ and $15.5 \%$ of total variances, respectively(as shown in Figure 7). The first axis RDA1 was positively correlated with water $\mathrm{NO}_{2}{ }^{-}-\mathrm{N}, \mathrm{NH}_{4}{ }^{+}-\mathrm{N}, \mathrm{COD} \mathrm{Mn}, \mathrm{TN}$, and TP, but negatively correlated with $\mathrm{Mn}, \mathrm{NO}_{3}{ }^{-}-\mathrm{N}, \mathrm{TOC}$, and Fe. The second axis of RDA2 was positively correlated with water algal cell concentration and $\mathrm{pH}$. Monte Carlo permutation tests also revealed that $\mathrm{Fe}, \mathrm{NO}_{2}{ }^{-}-\mathrm{N}$, and algal cell number were significantly correlated with the changes in the algal composition. The RDA diagram showed that JS lake, HLS lake, GT lake, JJ lake, and AX lake were located in the third quadrant, whereas CL lake, TX lake, and XS lake were located in the fourth quadrant. RDA results revealed the differences among the algal communities in the 16 different urban lakes, which had diverse physic-chemical water properties. An increasing number of studies have reported that nitrogen and phosphorus have a decisive effect on the growth of algae [75]. Nitrogen is not only a substance necessary for algal growth and metabolism, but also one of the main constituent elements of proteins and nucleic acids in the algae. In addition, studies have also proven that nitrogen in different forms could affect the absorption and utilization of algae [76,77]. Phosphorus is not only the main component of nucleic acids, proteins, and phospholipids, but also a substance necessary for the synthesis of chlorophyll. Therefore, phosphorus can further affect algal growth by affecting algae photosynthesis [78]. COD $\mathrm{Mn}$ is related to the state of organic pollution in water bodies, and is often used as an index to measure the organic matter content in lakes, reservoirs, and other water 
bodies. Qiu et al. [79] found that $\mathrm{COD}_{\mathrm{Mn}}$ has a significant effect on the concentration of algae and its community dynamic distribution in the sand lake, which is consistent with our research results. The ecological factor of $\mathrm{pH}$ is closely related to algal growth, and different algae have certain adaptation ranges [80], Furthermore, the changes of $\mathrm{pH}$ can increase or decrease the release of phosphorus from $\mathrm{Fe}$ and $\mathrm{Al}$ compounds to indirectly affect algal community structure [81]. For example, Rai et al. [82] investigated that the influence of $\mathrm{pH}$ on the growth of three species of cyanobacteria, two species of diatoms, and one species of planktonic green algae, and the result showed that six species of marine phytoplankton preferred near neutral to alkaline $\mathrm{pH}$. Therefore, $\mathrm{pH}$ has an important influence on the composition and distribution of algal species. These results give us a better understanding of the relationship between algal community structure and water quality.

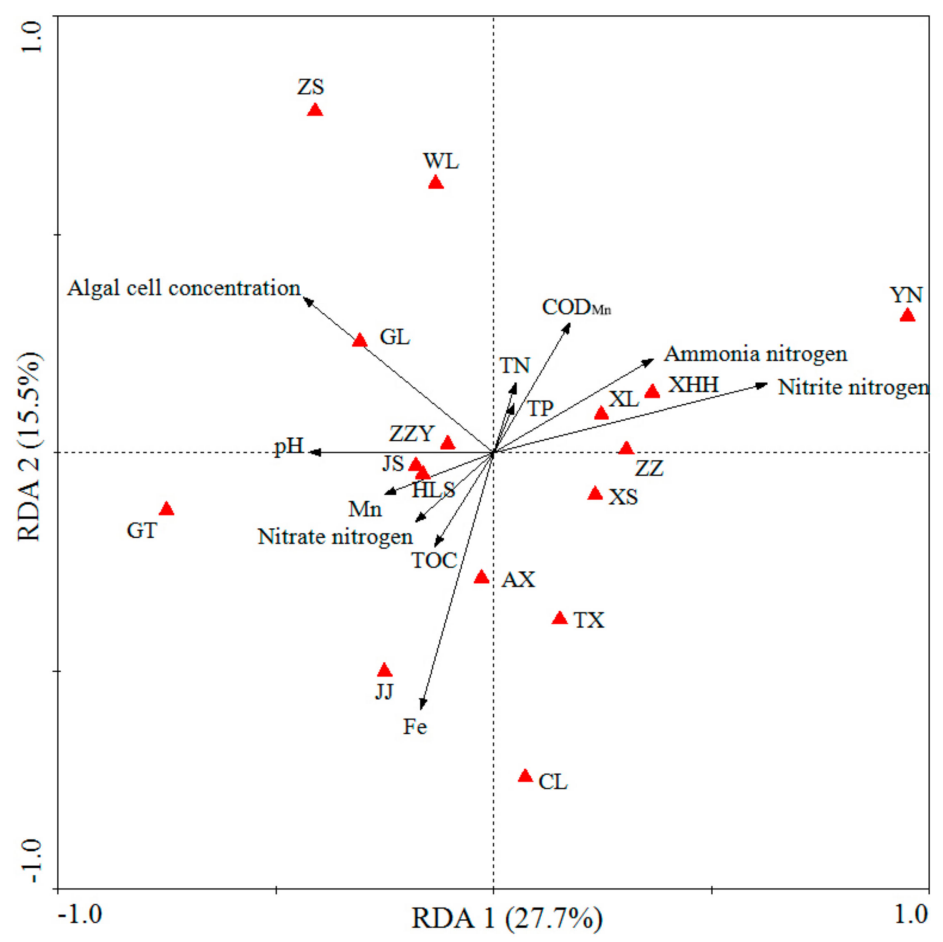

Figure 7. Redundancy analysis (RDA) of water algal communities in 16 geographically distributed urban lakes. Red triangles represent sampling points. For algal community, RDA1 explained 27.7\% and RDA2 explained $15.5 \%$ of the total variance. The factors of the water quality data are represented by arrows $(\mathrm{TN}=$ total nitrogen; $\mathrm{TP}=$ total phosphorus; $\mathrm{TOC}=$ total organic carbon). Water quality parameters that significantly correlated with algal community diversity are shown.

\section{Conclusions}

In summary, our results demonstrated that the water quality in 16urban lakes was significantly different; meanwhile, the pattern of algal communities was highly correlated with geographic location and water quality. By light microscopy analysis, a total of six phyla and 63 genera were identified, of which Bacillariophyta, Cyanophyta, and Chlorophyta were dominant. Our results also indicated that the dominant genera were Limnothrix sp., Synedra sp., Cyclotella sp., Nephrocytium sp., Melosira sp., and Scenedesmus sp. Network analysis suggested that the highly connected taxa (hub) were Fragilaria sp., Scenedesmus sp., and Stephanodiscus sp. Meanwhile, the water quality parameters of $\mathrm{NO}_{3}{ }^{-}-\mathrm{N}$ and $\mathrm{NH}_{4}{ }^{+}-\mathrm{N}$ had a significant impact on the structural composition of the algal community. RDA revealed that algal communities were greatly distinct in 16urban lakes and they were mainly affected by geographic location, $\mathrm{NO}_{2}{ }^{-}-\mathrm{N}, \mathrm{Fe}$, and algal cell concentration. Therefore, our studies of algal communities at a large spatial scale contribute to more effective governance and restoration of ecosystem functions in eutrophic urban lakes. 
Supplementary Materials: The following are available online at http://www.mdpi.com/1660-4601/17/3/1009/s1. The full name and abbreviations of urban lakes and water quality parameters associated with 16 different geographically distributed urban lakes, China (Figure S1).

Author Contributions: S.C. proposed this project; H.H. evaluated all the water parameters, analyzed the data, and wrote the manuscript; R.Z., K.L. and Y.M. gave suggestions on the design of Figures 1 and 6. M.Y. and L.X. gave comments on the early versions of the manuscript. All authors have read and agreed to the published version of the manuscript.

Acknowledgments: This research was supported by the National Natural Science Foundation of China (No. 51978561), International Science and Technology Cooperation Program in Shaanxi Province (No. 2018KW-011), and the Key Research and Development Project in Shaanxi Province (No. 2018ZDXM-SF-029). We are grateful to the four anonymous referees for their insightful comments on earlier version of this manuscript.

Conflicts of Interest: The authors declare no conflict of interest.

\section{References}

1. Garner, E.; Inyang, M.; Garvey, E.; Parks, J.; Glover, C.; Grimaldi, A.; Dickenson, E.; Sutherland, J.; Salveson, A.; Edwards, M.A.; et al. Impact of blending for direct potable reuse on premise plumbing microbial ecology and regrowth of opportunistic pathogens and antibiotic resistant bacteria. Water Res. 2019, 151, 75-86. [CrossRef]

2. Su, J.F.; Gao, C.Y.; Huang, T.L.; Gao, Y.C.; Bai, X.C.; He, L. Characterization and mechanism of the Cd(II) removal by anaerobic denitrification bacterium Pseudomonas sp. H117. Chemosphere 2019, 222, 970-979. [CrossRef]

3. Yang, J.; Yang, Y.; Chen, R.S.; Meng, X.Z.; Xu, J.; Qadeer, A.; Liu, M. Modeling and evaluating spatial variation of polycyclic aromatic hydrocarbons in urban lake surface sediments in Shanghai. Environ. Pollut. 2018, 235, 1-10. [CrossRef] [PubMed]

4. Metson, G.S.; Lin, J.; Harrison, J.A.; Compton, J.E. Linking terrestrial phosphorus inputs to riverine export across the United States. Water Res. 2017, 124, 177-191. [CrossRef] [PubMed]

5. Liu, Z.; Lompe, K.M.; Mohseni, M.; Bérubé, P.R.; Sauvé, S.; Barbeau, B. Biological ion exchange as an alternative to biological activated carbon for drinking water treatment. Water Res. 2020, 168, 115148. [CrossRef] [PubMed]

6. $\quad$ Eckert, E.M.; Di Cesare, A.; Kettner, M.T.; Arias-Andres, M.; Fontaneto, D.; Grossart, H.-P.; Corno, G. Microplastics increase impact of treated wastewater on freshwater microbial community. Environ. Pollut. 2018, 234, 495-502. [CrossRef]

7. Jeppesen, E.; Kronvang, B.; Meerhoff, M.; Sondergaard, M.; Hansen, K.M.; Andersen, H.E.; Lauridsen, T.L.; Liboriussen, L.; Beklioglu, M.; Ozen, A.; et al. Climate change effects on runoff, catchment phosphorus loading and lake ecological state, and potential adaptations. J. Environ. Qual. 2009, 38, 1930-1941. [CrossRef]

8. Yin, Q.; Fu, B.; Li, B.; Shi, X.; Inagaki, F.; Zhang, X.H. Spatial variations in microbial community composition in surface seawater from the Ultra-Oligotrophic center to rim of the south Pacific Gyre. PLoS ONE 2013, 8, e55148. [CrossRef]

9. Yu, Y.; Yan, Q.; Feng, W. Spatiotemporal heterogeneity of plankton communities in Lake Donghu, China, as revealed by PCR-denaturing gradient gel electrophoresis and its relation to biotic and abiotic factors. FEMS Microbiol. Ecol. 2008, 63, 328-337. [CrossRef]

10. Scherer, P.I.; Millard, A.D.; Miller, A.; Schoen, R.; Raeder, U.; Geist, J.; Zwirglmaier, K. Temporal dynamics of the microbial community composition with a focus on toxic cyanobacteria and toxin presence during harmful algal blooms in two south German Lakes. Front. Microbiol. 2017, 8, 2387. [CrossRef]

11. Sabater, S. Diatom communities as indicators of environmental stress in the Guadiamar River, S-W. Spain, following a major mine tailings spill. J. Appl. Phycol. 2000, 12, 113-124. [CrossRef]

12. Jelena, R.N.; Henner, H. Phytoplankton community and chlorophyll a as trophic state indices of Lake Skadar (Montenegro, Balkan). Environ. Sci. Pollut. Res. 2005, 3, 146-152.

13. Su, X.; Steinman, A.D.; Tang, X.; Xue, Q.; Zhao, Y.; Xie, L. Response of bacterial communities to cyanobacterial harmful algal blooms in Lake Taihu, China. Harmful Algae 2017, 68, 168-177. [CrossRef] [PubMed]

14. Xu, Y.G.; Li, A.J.; Qin, J.; Li, Q.; Ho, J.G.; Li, H.S. Seasonal patterns of water quality and phytoplankton dynamics in surface waters in Guangzhou and Foshan, China. Sci. Total Environ. 2017, 590-591, 361-369. [CrossRef] [PubMed] 
15. Liu, L.; Yang, J.; Yu, X.; Chen, G.; Yu, Z. Patterns in the composition of microbial communities from a subtropical river: Effects of environmental, spatial and temporal factors. PLoS ONE 2013, 8, e81232. [CrossRef] [PubMed]

16. Muyzer, G.; de Waal, E.C.; Uitterlinden, A.G. Profiling of complex microbial populations by denaturing gradient gel electrophoresis analysis of polymerase chain reaction-amplified genes coding for 16S rRNA. Appl. Environ. Microbiol. 1993, 59, 695-700. [CrossRef] [PubMed]

17. Jiang, Y.J.; He, W.; Liu, W.X.; Qin, N.; Ouyang, H.L.; Wang, Q.M.; Kong, X.Z.; He, Q.S.; Yang, C.; Yang, B.; et al. The seasonal and spatial variations of phytoplankton community and their correlation with environmental factors in a large eutrophic Chinese lake (Lake Chaohu). Ecol. Indic. 2014, 40, 58-67. [CrossRef]

18. Dodds, W.K.; Smith, V.H.; Lohman, K. Nitrogen and phosphorus relationships to benthic algal biomass in temperate streams. Can. J. Fish. Aquat. Sci. 2002, 59, 865-874. [CrossRef]

19. Peura, S.; Eiler, A.; Hiltunen, M.; Nykanen, H.; Tiirola, M.; Jones, R.I. Bacterial and phytoplankton responses to nutrient amendments in a boreal lake differ according to season and to taxonomic resolution. PLoS ONE 2012, 7, e38552. [CrossRef]

20. Vakkilainen, K.; Kairesalo, T.; Hietala, J.; Balayla, D.M.; Becares, E.; Van de Bund, W.J.; Van Donk, E.; Fernandez-Alaez, M.; Gyllstrom, M.; Hansson, L.A.; et al. Response of zooplankton to nutrient enrichment and fish in shallow lakes: A pan-European mesocosm experiment. Freshw. Biol. 2004, 49, 1619-1632. [CrossRef]

21. Zhang, H.H.; Chen, S.N.; Huang, T.L.; Ma, W.X.; Xu, J.L.; Sun, X. Vertical distribution of bacterial community diversity and water quality during the Reservoir thermal stratification. Int. J. Environ. Res. Public Health 2015, 12, 6933-6945. [CrossRef] [PubMed]

22. Kulshrestha, S.K.; Adholia, U.N.; Khan, A.A.; Bhatnagar, A.; Saxena, M.; Baghail, M. Community structure of planktons and macrozoobenthos, with special reference to pollution in the River Khan (India). Int. J. Environ. Stud. 1989, 35, 83-96. [CrossRef]

23. Zhang, H.H.; Chen, S.N.; Huang, T.L.; Shang, P.L.; Yang, X.; Ma, W.X. Indoor heating drives water bacterial growth and community metabolic profile changes in building tap pipes during the winter season. Int. J. Environ. Res. Public Health 2015, 12, 13649-13661. [CrossRef] [PubMed]

24. Diehl, S.; Berger, S.; Ptacnik, R.; Wild, A. Phytoplankton, light, and nutrients in a gradient of mixing depths: Field experiments. Ecology 2002, 83, 399-411. [CrossRef]

25. Maestrini, S.Y.; Berland, B.R.; Bréret, M.; Béchemin, C.; Poletti, R.; Rinaldi, A. Nutrients limiting the algal growth potential (AGP) in the Po River plume and an adjacent area, Northwest Adriatic Sea: Enrichment bioassays with the test algaeNitzschia closterium and Thalassiosira pseudonana. Estuaries 1997, 20, 416-429. [CrossRef]

26. Habib, O.A.; Tippett, R.; Murphy, K.J. Seasonal changes in phytoplankton community structure in relation to physico-chemical factors in Loch Lomond, Scotland. Hydrobiologia 1997, 350, 63-79. [CrossRef]

27. Zhang, H.H.; Feng, J.; Chen, S.N.; Zhao, Z.F.; Li, B.Q.; Wang, Y.; Jia, J.Y.; Li, S.L.; Wang, Y.; Yan, M.M.; et al. Geographical patterns of nirS gene abundance and nirS-Type denitrifying bacterial community associated with activated sludge from different wastewater treatment plants. Microb. Ecol. 2019, 77, 304-316. [CrossRef]

28. Liu, L.; Chen, H.; Liu, M.; Yang, J.R.; Xiao, P.; Wilkinson, D.M.; Yang, J. Response of the eukaryotic plankton community to the cyanobacterial biomass cycle over 6 years in two subtropical reservoirs. ISME J. 2019, 13, 2196-2208. [CrossRef]

29. Berdjeb, L.; Parada, A.; Needham, D.M.; Fuhrman, J.A. Short-term dynamics and interactions of marine protist communities during the spring-summer transition. ISME J. 2018, 12, 1907-1917. [CrossRef]

30. Morrien, E.; Hannula, S.E.; Snoek, L.B.; Helmsing, N.R.; Zweers, H.; de Hollander, M.; Soto, R.L.; Bouffaud, M.L.; Buee, M.; Dimmers, W.; et al. Soil networks become more connected and take up more carbon as nature restoration progresses. Nat. Commun. 2017, 8, 14349. [CrossRef]

31. Zhou, J.; Deng, Y.; Luo, F.; He, Z.; Tu, Q.; Zhi, X. Functional molecular ecological networks. mBio 2010, 1, e00169-10-e00169-19. [CrossRef] [PubMed]

32. Bascompte, J. Networks in ecology. Basic Appl. Ecol. 2007, 8, 485-490. [CrossRef]

33. Montoya, J.M.; Pimm, S.L.; Solé, R.V. Ecological networks and their fragility. Nature 2006, 442, $259-264$. [CrossRef] [PubMed] 
34. Zhang, H.H.; He, H.Y.; Chen, S.N.; Huang, T.T.; Lu, K.Y.; Zhang, Z.H.; Wang, R.; Zhang, X.Y.; Li, H.L. Abundance of antibiotic resistance genes and their association with bacterial communities in activated sludge of wastewater treatment plants: Geographical distribution and network analysis. J. Environ. Sci. 2019, 82, 24-38. [CrossRef]

35. Kang, P.L.; Hang, T.L.; Zhang, H.H.; Chen, S.N.; Shang, P.L.; Feng, J.; Jia, J.Y. Water quality and diversity of denitrifier community structure of typical scenic water bodies in Xi'an. Environ. Sci. Pollut. Res. 2017, 38, 5174-5183.

36. Shi, J.C.; Huang, T.L.; Wen, G.; Liu, F.; Qiu, X.P.; Wang, B.S. The variation characteristic of sulfides and VOSc in a source water reservoir and its control using a water-lifting aerator. Int. J. Environ. Res. Public Health 2016, 13, 427. [CrossRef]

37. Nazeer, M.; Wong, M.S.; Nichol, J.E. A new approach for the estimation of phytoplankton cell counts associated with algal blooms. Sci. Total Environ. 2017, 590-591, 125-138. [CrossRef]

38. Shen, Y.R.; Zhang, Z.S.; Gong, X.J.; Gu, M.R.; Shi, Z.X.; Wei, Y.X. Modern Biomonitoring Techniques Using Freshwater Microbiota; China Architecture and Building Press: Beijing, China, 1990.

39. Zhang, Z.S.; Huang, X.F. Research Methods of Freshwater Plankton; Science Press: Beijing, China, 1991.

40. Hu, H.J.; Wei, Y.X. The Freshwater Algae of China; Science and Technology Press: Beijing, China, 2006.

41. Newman, M.E.J. Communities, modules and large-scale structure in networks. Nat. Phys. 2012, 8, 25-31. [CrossRef]

42. Sun, W.; Krumins, V.; Dong, Y.; Gao, P.; Ma, C.; Hu, M.; Li, B.; Xia, B.; He, Z.; Xiong, S. A combination of stable isotope probing, Illumina Sequencing, and co-occurrence network to investigate thermophilic Acetate and lactate utilizing bacteria. Microb. Ecol. 2018, 75, 113-122. [CrossRef]

43. Blondel, V.D.; Guillaume, J.L.; Lambiotte, R.; Lefebvre, E. Fast unfolding of communities in large networks. J. Stat. Mech. Theory Equip. 2008, 2008, 10008. [CrossRef]

44. Jacomy, M.; Venturini, T.; Heymann, S.; Bastian, M. ForceAtlas2, a continuous graph layout algorithm for handy network visualization designed for the Gephi Software. PLoS ONE 2014, 9, e98679. [CrossRef] [PubMed]

45. Beisser, D.; Klau, G.W.; Dandekar, T.; Müller, T.; Dittrich, M.T. Binet: An R-Package for the functional analysis of biological networks. Bioinformatics 2010, 26, 1129-1130. [CrossRef] [PubMed]

46. Parulekar, N.; Kolekar, P.; Jenkins, A.; Kleiven, S.; Utkilen, H.; Johansen, A.; Sawant, S.; Kulkarni-Kale, U.; Kale, M.; Sæbø, M. Characterization of bacterial community associated with phytoplankton bloom in a eutrophic lake in South Norway using 16S rRNA gene amplicon sequence analysis. PLoS ONE 2017, 12, e0173408. [CrossRef]

47. Legendre, P.; Oksanen, J.; ter Braak, C.; Legendre, P.; Oksanen, J.; Braak, C.J.F. Testing the significance of canonical axes in redundancy analysis. Methods Ecol. Evol. 2011, 2, 269-277. [CrossRef]

48. Yang, J.; Jiang, H.; Wu, G.; Liu, W.; Zhang, G. Distinct factors shape aquatic and sedimentary microbial community structures in the lakes of western China. Front. Microbiol. 2016, 7, 1782. [CrossRef] [PubMed]

49. Xiong, J.; Liu, Y.; Lin, X.; Zhang, H.; Zeng, J.; Hou, J.; Yang, Y.; Yao, T.; Knight, R.; Chu, H. Geographic distance and $\mathrm{pH}$ drive bacterial distribution in alkaline lake sediments across Tibetan Plateau. Environ. Microbiol. 2012, 14, 2457-2466. [CrossRef] [PubMed]

50. Logares, R.; Lindstrom, E.S.; Langenheder, S.; Logue, J.B.; Paterson, H.; Laybourn-Parry, J.; Rengefors, K.; Tranvik, L.; Bertilsson, S. Biogeography of bacterial communities exposed to progressive long-term environmental change. ISME J. 2013, 7, 937-948. [CrossRef]

51. Souffreau, C.; Van der Gucht, K.; van Gremberghe, I.; Kosten, S.; Lacerot, G.; Lobao, L.M.; de Moraes Huszar, V.L.; Roland, F.; Jeppesen, E.; Vyverman, W.; et al. Environmental rather than spatial factors structure bacterioplankton communities in shallow lakes along a $>6000 \mathrm{~km}$ latitudinal gradient in South America. Environ. Microbiol. 2015, 17, 2336-2351. [CrossRef]

52. Crab, R.; Avnimelech, Y.; Defoirdt, T.; Bossier, P.; Verstraete, W. Nitrogen removal techniques in aquaculture for a sustainable production. Aquaculture 2007, 270, 1-14. [CrossRef]

53. Lu, L.; Tan, H.; Luo, G.; Liang, W. The effects of Bacillus subtilis on nitrogen recycling from aquaculture solid waste using heterotrophic nitrogen assimilation in sequencing batch reactors. Bioresour. Technol. 2012, 124, 180-185. [CrossRef] 
54. Green, C.T.; Bekins, B.A.; Kalkhoff, S.J.; Hirsch, R.M.; Liao, L.; Barnes, K.K. Decadal surface water quality trends under variable climate, land use, and hydrogeochemical setting in Iowa, USA. Water Resour. Res. 2014, 50, 2425-2443. [CrossRef]

55. Sarier, N. Specific features of adsorption of azo dyes on fly ash. Russ. Chem. Bull. 2007, 56, 566-569. [CrossRef]

56. Andersson, M.G.I.; Berga, M.; Lindström, E.S.; Langenheder, S. The spatial structure of bacterial communities is influenced by historical environmental conditions. Ecology 2014, 95, 1134-1140. [CrossRef] [PubMed]

57. Shang, G.P.; Shang, J.C. Spatial and temporal variations of eutrophication in western Chaohu Lake, China. Environ. Monit. Assess. 2007, 130, 99-109. [CrossRef]

58. Yin, K.D.; Qian, P.Y.; Wu, M.C.S.; Chen, J.C.; Huang, L.M.; Song, X.Y.; Jian, W.J. Shift from P to N limitation of phytoplankton growth across the Pearl River estuarine plume during summer. Mar. Ecol. Prog. Ser. 2001, 221, 17-28. [CrossRef]

59. Huber, V.; Adrian, R.; Gerten, D. Phytoplankton response to climate warming modified by trophic state. Limnol. Oceanogr. 2008, 53, 1-13. [CrossRef]

60. Greenaway, A.M.; Gordon-Smith, D.A. The effects of rainfall on the distribution of inorganic nitrogen and phosphorus in Discovery Bay, Jamaica. Limnol. Oceanogr. 2006, 51, 2206-2220. [CrossRef]

61. Yang, J.; Yu, X.; Liu, L.; Zhang, W.; Guo, P. Algae community and trophic state of subtropical reservoirs in southeast Fujian, China. Environ. Sci. Pollut. Res. 2012, 19, 1432-1442. [CrossRef]

62. Moustaka-Gouni, M.; Vardaka, E.; Tryfon, E. Phytoplankton species succession in a shallow Mediterranean lake (L. Kastoria, Greece): Steady-state dominance of Limnothrix redekei, Microcystis aeruginosa and Cylindrospermopsis raciborskii. Hydrobiologia 2007, 575, 129-140. [CrossRef]

63. Atkins, R.; Rose, T.; Brown, R.S.; Robb, M. The Microcystis cyanobacteria bloom in the Swan River February 2000. Water Sci. Technol. 2001, 43, 107-114. [CrossRef]

64. Wagner, C.; Adrian, R. Cyanobacteria dominance: Quantifying the effects of climate change. Limnol. Oceanogr. 2009, 54, 2460-2468. [CrossRef]

65. Carvalho, L.; Miller, C.A.; Scott, E.M.; Codd, G.A.; Davies, P.S.; Tyler, A.N. Cyanobacterial blooms: Statistical models describing risk factors for national-scale lake assessment and lake management. Sci. Total Environ. 2011, 409, 5353-5358. [CrossRef] [PubMed]

66. Jun, H.B.; Lee, Y.J.; Lee, B.D.; Knappe, D.R.U. Effectiveness of coagulants and coagulant aids for the removal of filter-clogging Synedra. J. Water Supply Res. 2001, 50, 135-148. [CrossRef]

67. Henderson, R.; Parsons, S.A.; Jefferson, B. The impact of algal properties and pre-oxidation on solid-liquid separation of algae. Water Res. 2008, 42, 1827-1845. [CrossRef] [PubMed]

68. Bracht, B.B.; Stone, J.R.; Fritz, S.C. A diatom record of late Holocene climate variation in the northern range of Yellowstone National Park, USA. Quatern. Int. 2008, 188, 149-155. [CrossRef]

69. Saros, J.E.; Anderson, N.J. The ecology of the planktonic diatom Cyclotella and its implications for global environmental change studies. Biol. Rev. 2015, 90, 522-541. [CrossRef]

70. Barberan, A.; Bates, S.T.; Casamayor, E.O.; Fierer, N. Using network analysis to explore co-occurrence patterns in soil microbial communities. ISME J. 2012, 6, 343-351. [CrossRef]

71. Zhang, H.H.; Zhao, Z.F.; Chen, S.N.; Wang, Y.; Feng, J.; Jia, J.Y.; Kang, P.L.; Li, S.L. Geographical patterns of denitrifying bacterial communities associated with different urban lakes. RSC Adv. 2018, 8, 17079-17090. [CrossRef]

72. Figueredo, C.C.; von Rückert, G.; Cupertino, A.; Pontes, M.A.; Fernandes, L.A.; Ribeiro, S.G.; Maran, N.R.C. Lack of nitrogen as a causing agent of Cylindrospermopsis raciborskii intermittent blooms in a small tropical reservoir. FEMS Microbiol. Ecol. 2014, 87, 557-567. [CrossRef]

73. Faust, K.; Raes, J. Microbial interactions: From networks to models. Nat. Rev. Microbiol. 2012, 10, 538-550. [CrossRef]

74. Shi, S.; Nuccio, E.E.; Shi, Z.J.; He, Z.; Zhou, J.; Firestone, M.K. The interconnected rhizosphere: High network complexity dominates rhizosphere assemblages. Ecol. Lett. 2016, 19, 926-936. [CrossRef] [PubMed]

75. Calijuri, M.C.; Dos Santos, A.C.A.; Jati, S. Temporal changes in the phytoplankton community structure in a tropical and eutrophic reservoir (Barra Bonita, S.P.-Brazil). J. Plankton Res. 2002, 24, 617-634. [CrossRef]

76. Liu, L.; Yang, J.; Lv, H.; Yu, X.; Wilkinson, D.M.; Yang, J. Phytoplankton communities exhibit a stronger response to environmental changes than bacterioplankton in three subtropical reservoirs. Environ. Sci. Technol. 2015, 49, 10850-10858. [CrossRef] 
77. Yamaguchi, H.; Sakamoto, S.; Yamaguchi, M. Nutrition and growth kinetics in nitrogen and phosphorus limited cultures of the novel red tide flagellate Chattonella ovata (Raphidophyceae). Harmful Algae 2008, 7 , 26-32. [CrossRef]

78. Gallardo Rodríguez, J.J.; Sánchez Mirón, A.; Cerón García, M.D.C.; Belarbi, E.H.; García Camacho, F.; Chisti, Y.; Molina Grima, E. Macronutrients requirements of the dinoflagellate Protoceratium reticulatum. Harmful Algae 2009, 8, 239-246. [CrossRef]

79. Qiu, X.C.; Zhao, H.X.; Sun, X.X. Studies on relationship of phytoplankton and water environmental factors in Shahu Lake. J. Environ. Sci. China 2012, 33, 2265-2271.

80. Shi, D.; Xu, Y.; Morel, F.M.M. Effects of the $\mathrm{pH} / \mathrm{pCO}_{2}$ control method on medium chemistry and phytoplankton growth. Biogeosciences 2009, 6, 1199-1207. [CrossRef]

81. Elser, J.J.; Marzolf, E.R.; Goldman, C.R. Phosphorus and nitrogen limitation of phytoplankton growth in the freshwaters of north america: A review and critique of experimental enrichments. Can. J. Fish. Aquat. Sci. 1990, 47, 1468-1477. [CrossRef]

82. Kim, L.H.; Choi, E.; Stenstrom, M.K. Sediment characteristics, phosphorus types and phosphorus release rates between river and lake sediments. Chemosphere 2003, 50, 53-61. [CrossRef]

(C) 2020 by the authors. Licensee MDPI, Basel, Switzerland. This article is an open access article distributed under the terms and conditions of the Creative Commons Attribution (CC BY) license (http://creativecommons.org/licenses/by/4.0/). 